\title{
GeoPark Araripe e a geodiversidade do sul do Estado do Ceará, Brasil
}

\author{
GeoPark Araripe and the geodiversity of the south of Ceara, Brazil
}

MOURA-FÉ ${ }^{1}$, M. M.

marcelo.mourafe@urca.br

\begin{abstract}
Resumo
Componente da Rede Global de Geoparques da UNESCO (Organização das Nações Unidas para a Educação, Ciência e Cultura), o GeoPark Araripe apresenta uma notável geodiversidade no seu conjunto de 9 (nove) geossítios abertos para visitação pública. Essa geodiversidade reflete uma história geológicageomorfológica antiga e significativa, a qual coaduna com eventos importantes da história natural do planeta Terra. Buscando promover a conservação desse patrimônio natural, o GeoPark Araripe fomenta a utilização conservacionista dos seus geossítios em consonância com o desenvolvimento socioeconômico sustentável das comunidades locais, sobretudo, aquelas situadas nas proximidades dos geossítios. Para isso, o território dos 6 municípios que o compõem são objeto de estratégias de geoconservação que devem considerar as particularidades regionais e a riqueza cultural do Cariri cearense (histórica, antropológica, arqueológica e artística), notadamente, o geoturismo e a geoeducação. $\mathrm{O}$ objetivo principal deste artigo é apresentar a geodiversidade da região sul do Estado do Ceará, o Cariri cearense, mais precisamente os geossítios do GeoPark Araripe.
\end{abstract}

Palavras-chave: Geoconservação. Geoturismo.

Geossítios

\begin{abstract}
Component of Geoparks Global Network (GGN) of UNESCO (United Nations Educational, Scientific and Cultural Organization), the Araripe GeoPark has a remarkable geodiversity as a whole of nine (9) geosites open to the public. This geodiversity reflects an ancient and significant geological, geomorphological history, which is consistent with important events in the natural history of planet Earth. Seeking to promote the conservation of this natural heritage, the Araripe GeoPark fosters conservationist use of its geosites in line with the sustainable socio-economic development of local communities, especially those located in the vicinity of geosites. For this, the territory of six municipalities that comprise it are the subject of geoconservation strategies should consider the regional and cultural richness of Ceará Cariri (historical, anthropological, archaeological and artistic), notably, geotourism and geoeducation. The main purpose of this article is to present the geodiversity of the south of Ceara region, the Cariri of Ceara, more precisely the geosites of Araripe GeoPark.
\end{abstract}

Keywords: Geoconservation. Geotourism. Geosistes.

\section{INTRODUÇÃO}

O Geopark Araripe, primeiro geoparque das Américas e do hemisfério sul com selo da UNESCO e componente da Rede Global de Geoparques (Global Geoparks Network - GGN), foi criado em 2006 e situa-se na região sul do Ceará, no contexto geológico da bacia sedimentar do Araripe e geomorfológico da Chapada do Araripe. O GeoPark Araripe (GA) possui atualmente 9 (nove) geossítios abertos para visitação e com amplas possibilidades de crescimento, já que existem outros 17 (dezessete) geossítios identificados, que ainda não estão totalmente inventariados e que, por uma questão de preservação e precaução, ainda não estão abertos para visitação pública.

Apesar das possibilidades e do planejamento de ampliação à curto prazo do número de geossítios abertos para visitação, o GA já possui ambientes de grande relevância científica e educacional para que as atividades geoturística e de geoeducação sejam ainda mais desenvolvidas na região. 
Contudo, é importante que ocorra cada vez mais o engajamento do GA na GGN e a maior inserção social do projeto na região para que haja a sua efetiva utilização e o cumprimento dos seus objetivos fundamentais: a promoção da conservação do seu patrimônio natural (com ênfase na geodiversidade e considerando a biodiversidade) e cultural, em consonância com o desenvolvimento socioeconômico sustentável das comunidades locais.

Nesse contexto, o objetivo principal deste artigo é apresentar a geodiversidade da região sul do estado do Ceará, o Cariri cearense, mais precisamente os geossítios do GeoPark Araripe (Figura 1), os quais estão espalhados no contexto territorial de 6 (seis) municípios (Crato, Juazeiro do Norte, Barbalha, Missão Velha, Nova Olinda e Santana do Cariri).

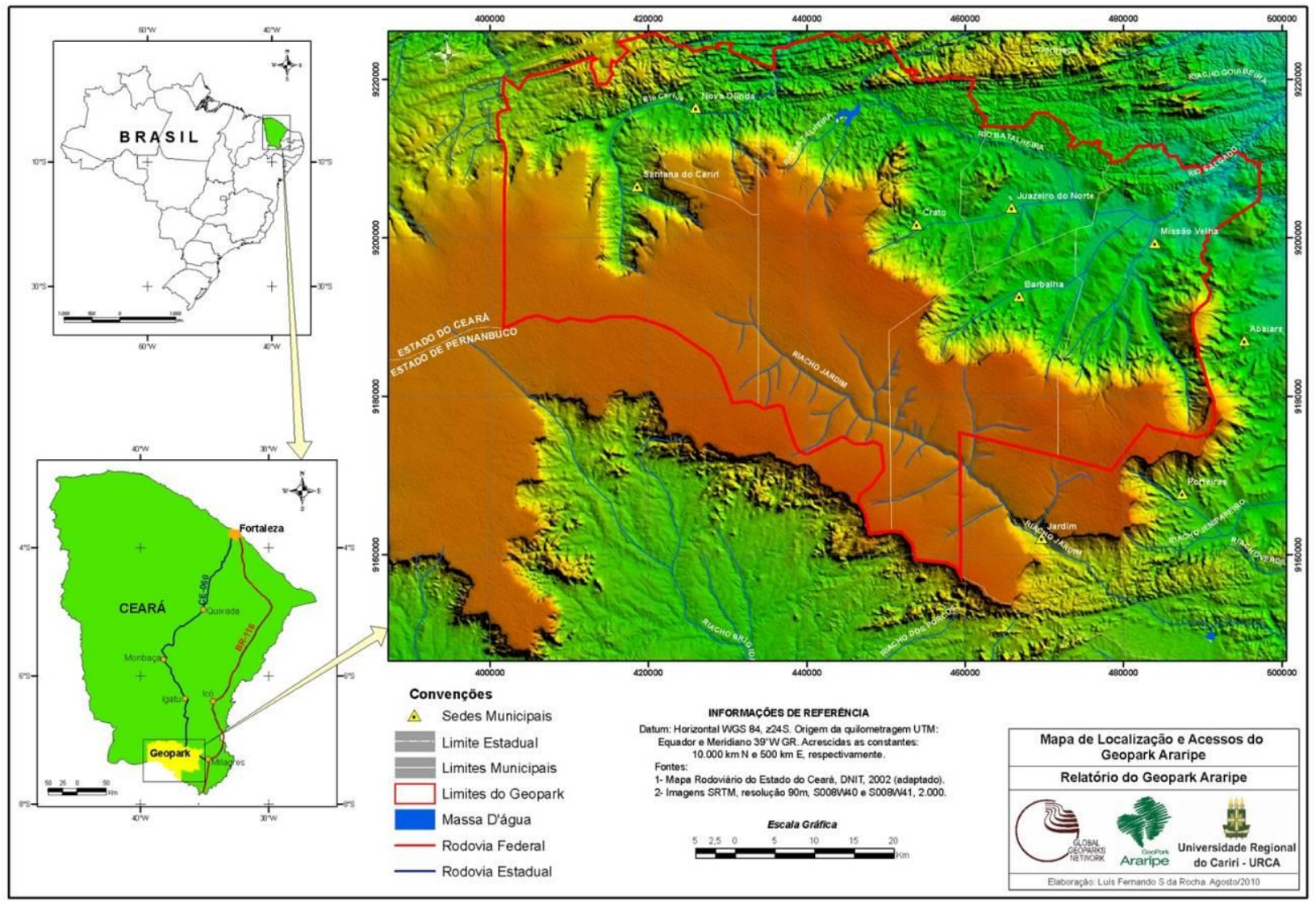

Figura 01. Área do GeoPark Araripe no contexto da Chapada do Araripe. Fonte: Ceará (2012).

\section{METODOLOGIA}

A discussão teórica apresentada aqui, deriva da tese de doutorado do autor (MOURA-FÉ, 2015a), cujo itinerário metodológico é compartimentado em duas linhas: no embasamento teórico, centrado na abordagem geomorfológica da geodiversidade, e na utilização de um contingente técnico associado. 
No tocante às técnicas de pesquisa, os procedimentos desenvolvidos foram baseados, por um lado, no criterioso levantamento bibliográfico, com a realização de um estudo sistematizado, investigando materiais publicados, sobretudo, em periódicos de revistas científicas estrangeiras e nacionais, com levantamento dos principais referenciais teóricos e metodológicos, visando, sobremaneira, a conceituação científica e aplicada da geodiversidade, geoconservação, geoturismo e da geoeducação.

Em paralelo, foram agregadas informações e experiências pertinentes às práticas profissionais científicas e educativas desenvolvidas em diversos levantamentos de campo realizados, os quais, dentre outros objetivos, propiciaram a caracterização básica da geodiversidade do GeoPark Araripe, apresentada aqui com ênfase nos geossítios abertos para visitação.

\section{RESULTADOS E DISCUSSÃO}

A geodiversidade é o resultado da interação de diversos fatores, como as rochas, o clima, os seres vivos, entre outros, possibilitando o aparecimento de paisagens distintas em todo o mundo (BRILHA, 2005), integrando a diversidade geológica (rochas, minerais e fósseis), geomorfológica (formas de relevo) e pedológica (solos), além dos processos que lhes originaram (BÉTARD et al., 2011) e lhes modelam de forma dinâmica e integrada atualmente (MOURA-FÉ, 2015a).

Enquanto testemunha científica dos acontecimentos que marcaram a história evolutiva da Terra, a geodiversidade deve ser conservada como parte fundamental do patrimônio natural e utilizada para fins científicos, didáticos, culturais e geoturísticos (GODOY et al., 2013), na forma de sítios naturais, os geossítios, com base nos seus 7 (sete) valores fundamentais: intrínseco, cultural, estético, econômico, funcional, científico e didático (MOCHIUTTI et al., 2012).

Por conta do valor econômico, sobretudo, muitas são as ameaças à geodiversidade, onde a sociedade é o principal agente modificador e degradador (GRAY, 2005). Na tentativa de reverter esse quadro de vulnerabilidade, têm sido criadas estratégias visando à conservação da geodiversidade, as quais podem ser aglutinadas na geoconservação, que conceitualmente "é um ramo de atividade científica que tem como objetivo a caracterização, conservação e gestão do patrimônio geológico e processos naturais associados" (BRILHA, 2005, p. 51).

Dentro desse conjunto de atividades geoconservacionistas destacam-se duas: o geoturismo e a geoeducação.

O geoturismo é a atividade turística com conotação geocientífica que propõe a visita organizada e orientada a locais que testemunham uma fase do passado ou da história de origem e evolução do planeta, que se notabilizam como uma herança coletiva e que devem ser preservados para as gerações futuras. Neste contexto, se inclui o conhecimento científico sobre a gênese da 
paisagem, os processos envolvidos e os testemunhos registrados em rochas, relevos e solos (SILVA e PERINOTTO, 2007; VIEIRA e CUNHA, 2004).

Em geoturismo o "geo" significa geologia (ou geodiversidade) e a parte "turismo" significa visitar geossítios, aprender, entender, valorizar e se envolver, combinando as geociências com os componentes do turismo (SCHOBBENHAUS e SILVA, 2012) sob 3 (três) motivações fundamentais: recreação, lazer e aprendizado (BENTO e RODRIGUES, 2010; 2009; SOUSA e NASCIMENTO, 2007).

Num quadro mais amplo e integrado, os conceitos de geodiversidade e geoconservação, juntamente com o geoturismo, formam o trinômio fundamental para a divulgação, valorização e conservação do patrimônio natural (BENTO e RODRIGUES, 2010) e seus geossítios, os quais se configuram como um elo entre esses conceitos, por serem os locais de ocorrência de geodiversidade, se configurarem como formas de geoconservação e como locais para o desenvolvimento da atividade geoturística (MOURA-FÉ, 2015b).

Conforme Moura-Fé (2015b) existem duas dimensões estratégicas para a implementação e fomento da atividade geoturística: a interpretação da paisagem e o fomento à educação ambiental, as quais projetam sua finalidade maior de geoconservação para escalas temporais diferentes: curto, médio e longo prazos, ao passo que a educação ambiental, dado seu maior poder de introspecção, sobretudo no público estudantil, projeta-se para as escalas temporais de maior escala.

Sendo assim, considerando a importância da geodiversidade e a ampla possibilidade de inserção da educação ambiental, Moura-Fé et al. (2016) propõem o estabelecimento e o desenvolvimento do conceito científico da geoeducação, entendida como um ramo específico da educação ambiental a ser aplicado na geoconservação do patrimônio natural, e que seja tratado, fomentado e desenvolvido nos âmbitos formais e/ou não formais do ensino.

Essas estratégias de geoconservação (geoturismo e geoeducação) no contexto do território do GeoPark Araripe, têm como foco os geossítios abertos para visitação, os quais serão apresentados na sequência com indicações dos valores agregados (MOCHIUTTI et al., 2012), informações gerais (CEARÁ, 2012), formas e potenciais de uso.

1 - Geossítio Colina do Horto (Juazeiro do Norte): valores científico e didático/educação e treinamento: ciclo das rochas; valor cultural/espiritual: pedras empilhadas por romeiros e passagem pela fenda na "Pedra do Pecado"; histórico: muro da resistência.

Localizado a $3 \mathrm{~km}$ da sede de Juazeiro do Norte, representa o modelado mais significativo do município, erigido sobre as litologias mais antigas da região, as quais compõem o embasamento cristalino, com idade aproximada de $650 \mathrm{Ma}$. Sobretudo por conta da história e da religiosidade em torno da figura do Padre Cícero Romão (Figura 2), é o principal local de visitação turística de toda a 
região, com destaque para a trilha do Santo Sepulcro e suas diversas atratividades, as quais versam desde a geodiversidade e passam pela história do Cariri.

2 - Geossítio Riacho do Meio (Barbalha): valores funcionais/saúde: micro clima; estocagem e reciclagem - concentração de nascentes (Figura 3); funções ecossistêmicas - espécies endêmicas: samambaia-açu e soldadinho do Araripe; valor estético das nascentes, flora e da paisagem geral.

Em meio à vegetação densa e úmida existem fontes naturais de água que surgem no contato de dois tipos de rochas: os arenitos permeáveis da Formação Exu, do topo da chapada, e os arenitos impermeáveis da Formação Arajara. Neste geossítio estão ainda preservados alguns exemplares da flora e fauna nativas do Araripe, que determina uma alta relevância ambiental-ecológica.

Com trilhas bem estruturadas, diversas atratividades e equipamentos instalados (miniauditório, restaurante, estacionamento, dentre outros) permite a realização de inúmeras atividades educativas e turísticas, as quais permanecem ganhando volume e representatividade, fomentadas para e pela comunidade local do Riacho do Meio.
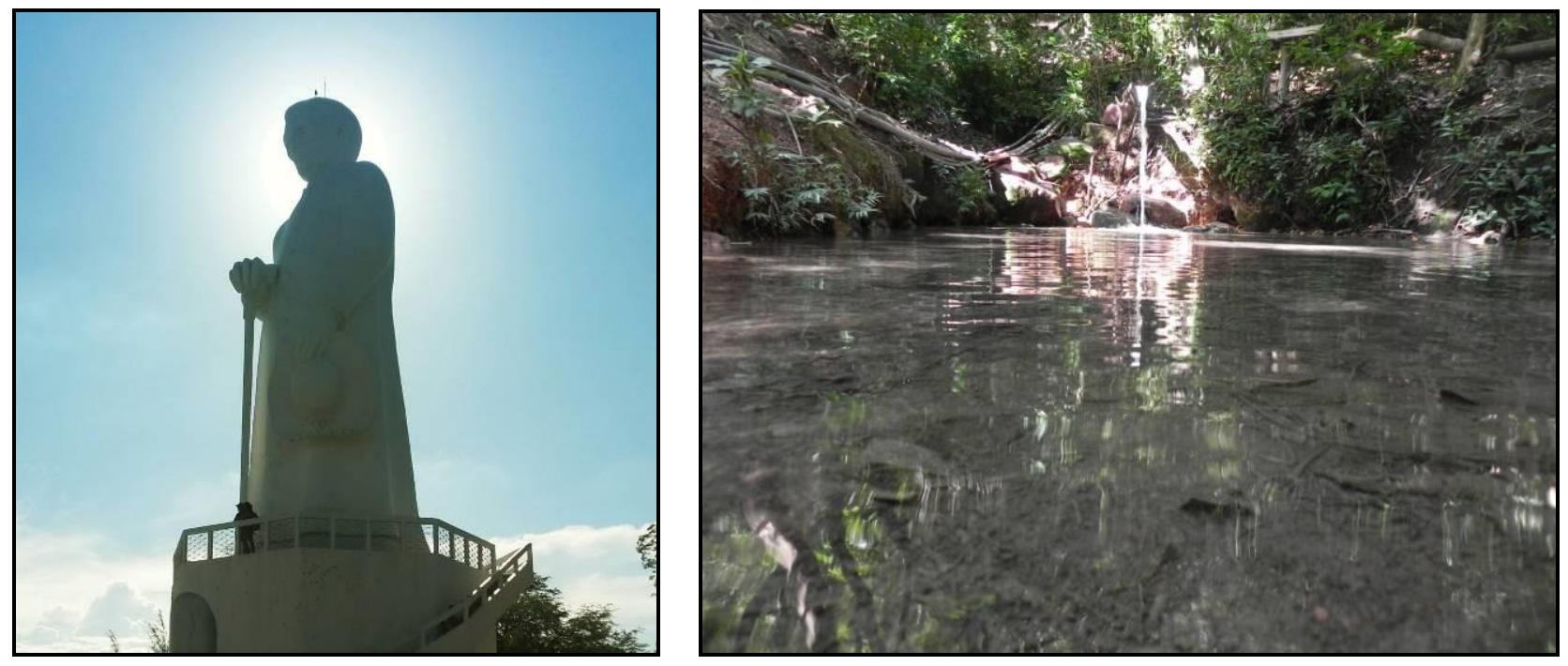

Figuras 02. Estátua do Padre Cícero, Geossítio Colina do Horto. Fonte: Marcelo Moura Fé (Mar/2016) Figura 03. Fonte Olho d'água branca. Fonte: Marcelo Moura Fé (Abr/2016)

3 - Geossítio Floresta Petrificada (Missão Velha): valores científico e didático/história da Terra: troncos fósseis (Figura 4).

Caracterizado por uma área de erosão que expõe as camadas de arenito da Formação Missão Velha, que apresentam cerca de 8 metros de espessura e onde ocorrem fragmentos de troncos petrificados com aproximadamente 145 Ma. Esses fósseis de troncos petrificados evidenciam que no Jurássico existiam colinas cobertas por florestas de coníferas (grupo dos pinheiros) na região, as quais eram recortadas por rios que transportavam os troncos caídos e que eram depois depositados em meio às areias e argilas, sendo fossilizados. 
Com forte apelo científico, a floresta petrificada encanta os visitantes do geossítio, o qual necessita de melhorias em suas trilhas, as quais devem ser realizadas em breve para garantir maior conforto aos turistas.

4 - Geossítio Cachoeira de Missão Velha (Missão Velha): valores científico e didático/história da Terra: icnofósseis; valor cultural/folclórico: Lenda da mãe d'água; valor estético: um dos cartões postais do Cariri (Figura 5).

Modelada geomorfologicamente no arenito da Formação Cariri (420 Ma - Siluriano), depositado por águas de um mar raso e antecedendo à formação da bacia do Araripe, a cachoeira de Missão Velha constitui um dos cartões postais de todo o Ceará. Apresenta iconofósseis, vestígios da atividade vital de antigos organismos, neste caso, invertebrados aquáticos (com aspecto vermiforme), e elementos que remontam à história da região em suas trilhas, bem como, per si, é foco de diversas lendas e referências dos índios Kariri, dentre elas, que o Cariri surgiu exatamente neste local.
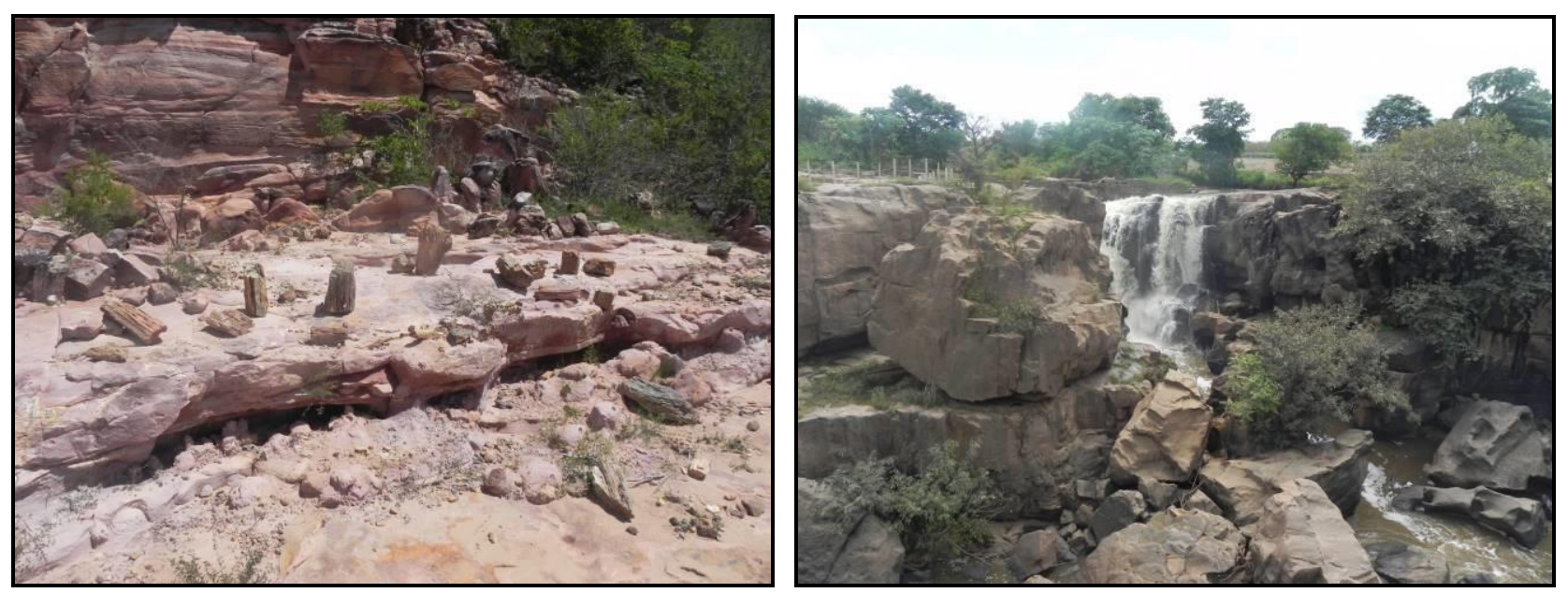

Figura 04. Exemplares de troncos fósseis da Floresta Petrificada. Fonte: Marcelo Moura Fé (Abr/2016)

Figura 05. Queda d'água principal da Cachoeira de Missão Velha. Fonte: Marcelo Moura Fé (Abr/2016)

5 - Geossítio Pedra Cariri (Nova Olinda) (Figura 6): valores científico e didático/história da Terra: Fósseis da formação Santana; valor econômico: calcário laminado; valor cultural: história da mineração na região.

Apresenta elevado valor científico devido à ocorrência de fósseis diversos e abundantes, como insetos, pterossauros, peixes e vegetais, em excepcional estado de conservação, os quais ocorrem na chamada "Pedra Cariri", um calcário disposto em finas camadas de sedimentos pertencentes ao membro Crato da Formação Santana, depositados há aproximadamente $112 \mathrm{Ma}$ (Cretáceo), quando neste local existia um lago de águas calmas, com brejos nas suas margens, onde uma biodiversidade abundante se desenvolvia. 
Nesse geossítio pode-se abordar tanto a história da mineração na região, fortemente apoiada na extração da "Pedra Cariri" quanto na delicada situação socioeconômica dos trabalhadores envolvidos atualmente nesta atividade, atrelada ao contexto da região e que precisa de atenção por parte do Poder Público e de políticas específicas.

6 - Geossítio Ponte de Pedra (Nova Olinda) (Figura 7): valor estético da ponte em si e da paisagem no entorno; valor científico e didático/educação e treinamento: feições de erosão fluvial.

Este geossítio, do tipo geomorfológico, corresponde a uma geoforma esculpida no arenito da Formação Exu (96 Ma - Cretáceo), resultado da erosão provocada pela água do córrego afluente do rio Carius, ao longo dos últimos milhões de anos. Os processos erosivos se deram de forma diferencial nos diferentes níveis de arenito (grossos e finos), ao passo que os níveis mais resistentes à erosão ficaram preservados, formando a ponte de pedra, outro singular cartão postal de todo o Ceará, visitado por inúmeros turistas em todas as épocas do ano.
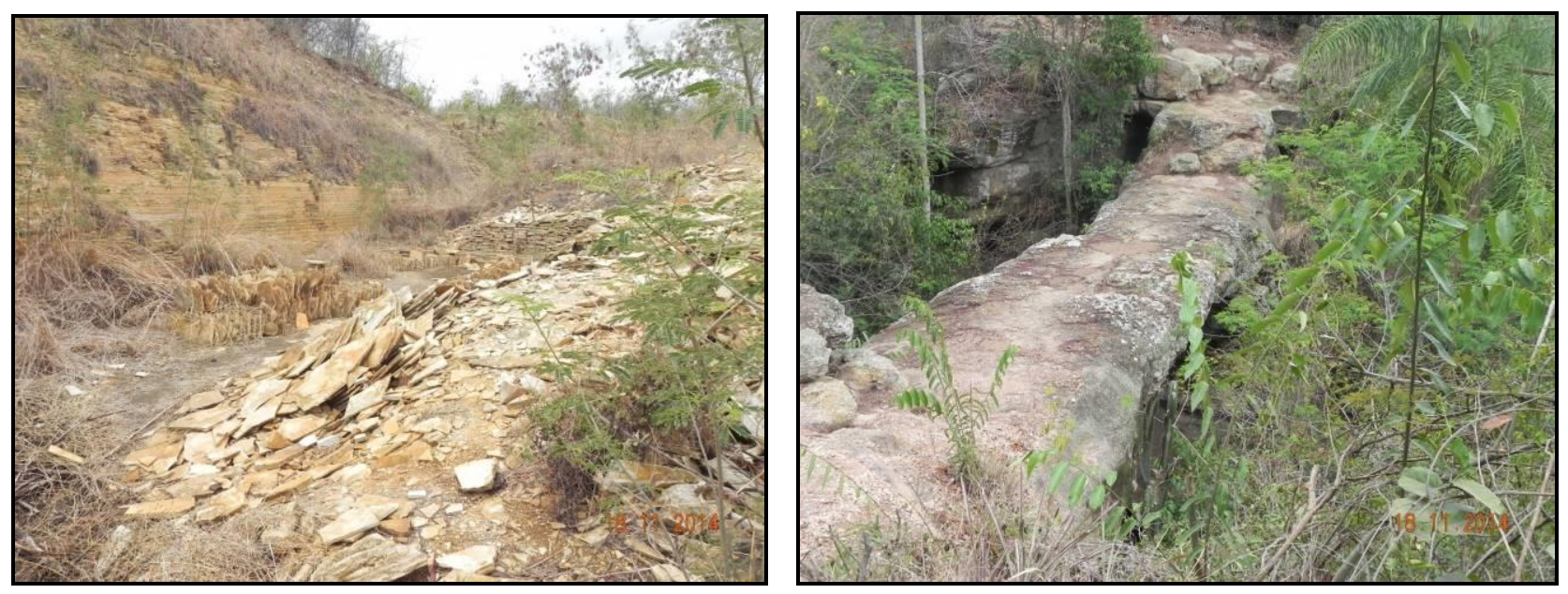

Figura 06. Camadas do calcário laminado da Formação Santana. Fonte: Marcelo Moura Fé (2016) Figura 07. Visão geral da Ponte de Pedra. Fonte: Marcelo Moura Fé (2014)

7 - Geossítio Parque dos Pterossauros (Santana do Cariri): valor científico e didático/história da Terra: fósseis.

Neste geossítio são feitas escavações paleontológicas em rochas do membro Romualdo (Formação Santana) (Figura 8), em busca de concreções calcárias que geralmente possuem fósseis, conhecidas popularmente como "pedras de peixe". As concreções calcárias existentes entre as camadas de folhelhos (lama petrificada do fundo da laguna) desta formação e apresentam tamanho e formas variadas, possuindo geralmente em seu interior macrofósseis tridimensionalmente preservados. Nestas concreções são encontrados restos de pterossauros, dinossauros, tartarugas e vegetais. 


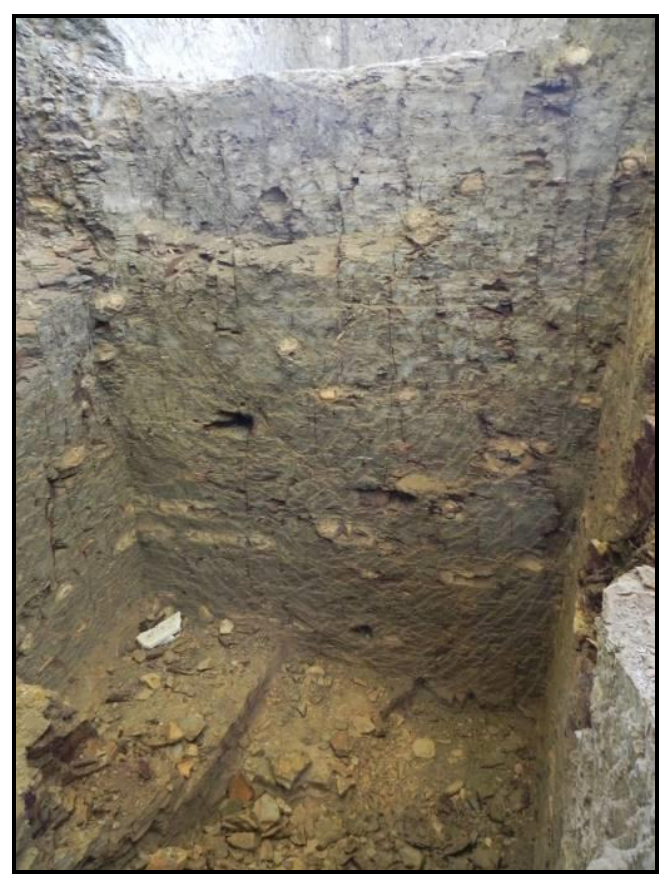

Figura 08. Escavação principal do Parque dos Pterossauros. Fonte: Marcelo Moura Fé (Mai/2016)

8 - Geossítio Pontal da Santa Cruz (Santana do Cariri): valor cultural/histórico: mirante do Pontal de Santa Cruz; valor funcional/funções ecossistêmicas: mata subúmida; valor estético da feição geomorfológica em si e de todo o entorno, visível a partir do mirante que permite a visão panorâmica de parte da Chapada do Araripe, do vale do rio Cariús e da sede do município de Santana do Cariri, permitindo assim diversas formas de interpretação da paisagem (Figura 9).

Formado pelo arenito da Formação Exu, este geossítio do tipo geomorfológico foi modelado na porção superior da escarpa da chapada do Araripe. A Formação Exu é a mais jovem da bacia do Araripe (90 Ma) sendo formada por arenitos coesos, atuando como uma capa resistente da chapada. Hidrologicamente, é considerado permeável, absorvendo facilmente as águas das chuvas, as quais acumulam-se nas camadas mais baixas, dando origem às nascentes.

9 - Geossítio Batateiras (Crato): valores científico e didático/história de pesquisa: sequência de arenitos e folhelhos betuminosos; valor cultural/folclórico: lenda dos índios Kariris; valor estético em diversas feições geomorfológicas fluviais, de diversas escalas.

Nas margens do rio Batateira (Figura 10) aflora uma intercalação de arenitos com folhelhos, ambos da Formação Rio Batateira, que registra o momento em que a região era caracterizada por ambiente fluvial/lacustre, sob um clima semiárido, há aproximadamente 115 Ma (Cretáceo).

Situado em uma Unidade de Conservação estadual, o Parque Sítio Fundão, tem-se ainda diversas atratividades em termos de biodiversidade (biomas Caatinga e Cerrado) e de cultura, na forma de 5 construções, dentre elas: uma murada erguida por ordem do imperador D. Pedro II, 
engenho de madeira com tração animal e uma casa de taipa em $1^{\circ}$ andar (FERNANDES et al., 2016).
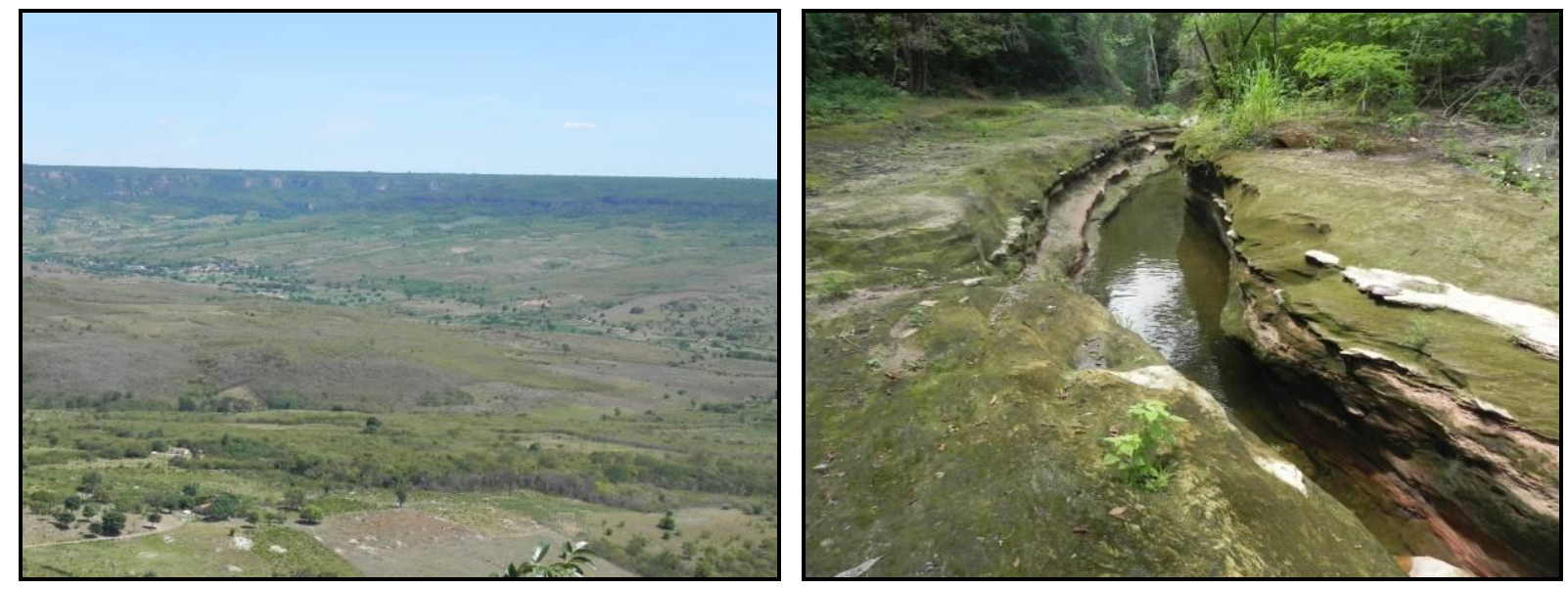

Figura 09. Visão panorâmica da Chapada do Araripe a partir do mirante. Fonte: Marcelo Moura Fé (Mai/2016) Figura 10. Rio Batateiras dissecando o areníto da formação homônima. Fonte: Marcelo Moura Fé (Abr/2016)

\section{CONSIDERAÇÕES FINAIS}

A geodiversidade da região do Cariri, notabilizada nos geossítios do GeoPark Araripe e atrelada à significativos elementos da biodiversidade e da cultura, proporciona inúmeras formas de realizar o geoturismo e atividades de geoeducação, fundamentais para promover o conhecimento e, por conseguinte, uma maior identificação e formas mais concretas de proteção e geoconservação desse patrimônio tão singular e tão importante para todos.

Tais atividades têm alcançado maior presença, relevância e importância sócioeconômica nos municípios do Cariri, o que, se considerando o potencial conhecido e ainda inexplorado da região e que deve ser utilizado de forma pensada, planejada e sustentável, podem e devem trazer maior desenvolvimento, sobretudo, para as comunidades locais, objetivos que estão no DNA do GeoPark Araripe e que são a essência do Cariri cearense.

\section{REFERÊNCIAS}

BENTO, L. C. M. e RODRIGUES, S. C. O Geoturismo como instrumento em prol da divulgação, valorização e conservação do patrimônio natural abiótico - uma reflexão teórica. Pesquisas em Turismo e Paisagens Cársticas, v. 3, n. 2, p. 55-65, Campinas-SP: 2010.

. Geomorfologia fluvial e Geoturismo. O potencial turístico de quedas d'água do município de Indianápolis, MG. Pesquisas em Turismo e Paisagens Cársticas, v. 1, n. 2, p. 59-70, Campinas-SP: 2009. 
BÉTARD, F.; PEUlVAST, J-P. e MAGALHÃES, A. O. Biodiversité, géodiversité et enjeux de leur conservation dans les montagnes humides du Nordeste brésilien. BAGF. Géographies, p. 17-26, Paris: 2011. BRILHA, J. B. R. Patrimônio geológico e geoconservação - a conservação da natureza na sua vertente geológica. Braga: Palimage, 2005. 190 p.

CEARÁ. Governo do estado do Ceará. Geopark Araripe: histórias da Terra, do Meio Ambiente e da Cultura. Projeto Cidades do Ceará, Crato-CE: 2012.

FERNANDES, P. A. S.; MOURA-FÉ, M. M.; VIEIRA, R. S.; PINHEIRO, M. A. Educação Ambiental Aplicada no Parque Estadual Sítio Fundão (Crato-CE). In SEABRA, G. (Org.). Educação Ambiental \& Biogeografia, v. I, p. 1585-1597. Ituiutaba-SP: Barlavento, 2016. 2360 p.

GODOY, L. H.; SARDINHA, D. S.; BERTINI, R. J.; CONCEIÇÃO, F. T.; DEL ROVERI, C. e MOREIRA, C. A. Potencial Geoparque de Uberaba (MG): geodiversidade e geoconservação. Sociedade \& Natureza, v. 25, n. 2, p. 395-410, Uberlândia-MG: 2013.

GRAY, M. Geodiversity and Geoconservation: what, why, and how? Geodiversity and Geoconservation, p. 4-12, 2005.

MOCHIUTTI, N. F.; GUIMARÃES, G. B.; MOREIRA, J. C.; LIMA, F. F. e FREITAS, F. I. Os valores da geodiversidade: geossítios do Geopark Araripe/CE. Anuário do Instituto de Geociências, v. 35, n. 1, p. 173-189, Rio de Janeiro-RJ: 2012.

MOURA-FÉ, M. M. Evolução Geomorfológica da Ibiapaba setentrional, Ceará: Gênese, Modelagem e Conservação. Tese de Doutorado apresentado ao PPGG da UFC, Fortaleza-CE, 2015a. 307 p.

Geoturismo: uma proposta de turismo sustentável e conservacionista para a Região Nordeste do Brasil. Sociedade \& Natureza, v. 27, n. 1, p. 53-66, Uberlândia-MG: 2015 b.

MOURA-FÉ, M. M.; PINHEIRO, M. V. A.; JACÓ, D. M.; OLIVEIRA, B. A. Geoeducação: a educação ambiental aplicada na geoconservação. In SEABRA, G. Educação Ambiental \& Biogeografia, v. II, p. 829842. Ituiutaba: Barlavento, 2016. 2762 p.

SCHOBBENHAUS, C. e SILVA, C. R. O papel do Serviço Geológico do Brasil na criação de geoparques e na conservação do patrimônio geológico. In SCHOBBENHAUS, C. e SILVA, C. R. (Org.) Geoparques do Brasil: propostas. Rio de Janeiro: CPRM, 2012.

SILVA, J. R. B. e PERINOTTO J. A. J. O Geoturismo na geodiversidade de Paraguaçu Paulista como modelo de geoconservação das estâncias. Global Tourism, v. 3, n. 2, 2007. 40 p.

SOUSA, D. C. e NASCIMENTO, M. A. L. Geoturismo no litoral de Icapuí/CE: uma alternativa de divulgação do patrimônio geológico. Revista de Geologia, v. 20, n. 2, p. 279-287, Fortaleza-CE: 2007.

VIEIRA, A. B. e CUNHA, L. Património Geomorfológico: tentativa de sistematização. Actas do III Seminário Latino Americano de Geografia Física, Puerto Vallarta (MEX): 2004.

Recebido em: 14/08/2016

Aceito para publicação em: 01/10/2016 